\title{
RANCANGAN PELATIHAN PENGUCAPAN KATA UNTUK MENINGKATKAN KELANCARAN MEMBACA SISWA KELAS 1 SD
}

\author{
Rawdhah Binti Yasa \\ UIN Ar-Raniry Banda Aceh, Jl. Syeikh Abdur Rauf Kopelma Darussalam \\ e-mail:rawdhah.yasa@gmail.com
}

\begin{abstract}
The aim of this study as a preliminary study in developing the exercises to improve reading fluency of students grade lof Primary School (SD). The study used a quasi- experimental method with Nonequivalent Control Group Design. The subjects were seven students in 1st grade, with age 7-8 years old, which consists of four students as an experimental group that received exercises of pronunciation as much as six times with a duration of 30-40 minutes and three students as a control group. Data on reading fluency obtained by measuring the average score of subject's reading ability within one minute. Measuring instrument used was a single paragraph which consists of a series of words / syllables that need to be mastered by children aged 7 years old. In this exercise the students practice for using their speech muscles suit the phonetic rules, so that the resulting pronunciation becomes more precise. The results showed that in the control group there was no increase reading fluency, while in the experimental group there was three student has increased their reading fluency but not to the another one. However, there were changing in the aspects of speed and accuracy among all subjects who received the pronunciation exercises.
\end{abstract}

Keywords: reading fluency, pronunciation exercises, phonetic rules

\begin{abstract}
Abstrak
Penelitian ini bertujuan sebagai studi awal bentuk pelatihan untuk meningkatkan kelancaran membaca pada siswa kelas 1 SD.Rancangan penelitian ini menggunakan metode quasi eksperimental, dengan Nonequivalent Control Group Design. Subjek penelitian adalah tujuh siswa kelas 1 SD usia 7-8 tahun, yang terdiri dari empat siswa sebagai kelompok eksperimen yang mendapat pelatihan pengucapan kata sebanyak enam kali dengan durasi 30-40 menit dan tiga orang siswa sebagai kelompok kontrol. Data mengenai kelancaran membaca diperoleh dari hasil pengukuran rata-rata kemampuan membaca subjek dalam waktu satu menit. Alat ukur yang digunakan adalah satu buah paragraf yang terdiri dari rangkaian kata/sukukata yang perlu dikuasai anak usia 7 tahun. Pada latihan ini siswa berlatih untuk menggerakkan otot alat ucap sesuai aturan fonetik, sehingga pengucapan yang dihasilkan menjadi lebih tepat. Hasil penelitian menunjukkan bahwa pada kelompok kontrol tidak terjadi peningkatan kelancaran membaca sedangkan pada kelompok eksperimen mengalami peningkatan kelancaran membaca pada tiga orang subjek dan tidak terdapat perubahan kelancaran membaca pada satu subjek. Namun jika dilihat hasil perubahan pada aspek kelancaran membaca yaitu aspek kecepatan dan ketepatan, maka terjadi peningkatan pada semua subjek penelitian yang mendapatkan latihan pengucapan kata.
\end{abstract}

Kata Kunci: Kelancaran membaca, latihan pengucapan kata, aturan fonetik

\section{PENDAHULUAN}

Kemampuan membaca merupakan salah satu fakor yang mempengaruhi keberhasilan belajar siswa di sekolah. Tujuan membaca adalah pemahaman yaitu dengan menerima atau memahami pesan yang terkandung dalam suatu teks/tulisan. Salah satu sebab siswa sulit untuk memahami isi bacaan adalah karena kemampuan membaca yang masih lambat (tidak lancar). Wulan (2009) mengatakan bahwa pemahaman membaca dan kemam- puan akademis siswa dipengaruhi oleh kelancaran membaca suatu bacaan. Ada kesinambungan yang kuat antara kemampuan membaca pada awal anak masuk sekolah dan performansi akademik pada masa selanjutnya.

Kelancaran membaca merupakan dasar kesuksesan akademik siswa. Menzies, et.al. (dalam Kumara, 2010) mengungkapkan bahwa anak yang mengalami ketidaklancaran membaca di kelas awal umumnya akan mengalami kesulitan yang sama di kelas selanjutnya. Di 
Indonesia, banyak penelitian maupun survey yang mengungkapkan lemahnya kemampuan membaca siswanya, salah satunya hasil tes membaca pada tahun 1996 yang diselenggarakan oleh International of Educational Association (sebuah assosiasi internasional) yang menyelenggarakan riset untuk evaluasi dan pencapaian pendidikan di sejumlah negara, menunjukkan bahwa Indonesia berada pada peringkat bawah dalam hal kemampuan membaca (Kompas, 2 mei 1999). Studi tentang kemampuan mem-baca tersebut mengukur tingkat keberak-saraan yang dicapai murid sekolah dasar.

Kelancaran membaca erat kaitannya dengan pemahaman. Samuel (2006) mendefinisikan kelancaran membaca sebagai kemampuan untuk mengenal kata (decoding) dan memahami (comprehension) suatu bacaan pada waktu yang bersamaan. Samuel (2006) menyimpulkan tiga komponen yang terdapat pada $k e-$ lancaran membaca yaitu: (1). Kecepatan, (2). Ketepatan, dan (3). Intonasi. Pada penelitian ini, peneliti hanya membatasi cakupan penelitian pada dua aspek pertama yaitu kecepatan dan ketepatan dalam membaca.

Peneliti melakukan survey awal pada siswa kelas I di salah satu SDN di Bandung. Berdasarkan wawancara dengan guru kelas I, dijelaskan bahwa rata-rata siswa di kelas I sudah mengenal huruf dan dapat membaca dalam bentuk kata dan kalimat sederhana. Kecepatan rata-rata membaca siswa kelas I adalah berkisar antara 40-50 kata permenit. Tetapi, beberapa diantara mereka masih belum bisa membaca dengan lancar bahkan masih mengeja. Kecepatan membaca siswa tersebut masih di bawah 25 kata permenit. Siswa tersebut biasanya lambat dalam membaca kata-perkata. Terutama saat dihadapkan pada bacaan baru.

Peneliti selanjutnya melakukan observasi terhadap kemampuan membaca nyaring (bersuara) pada duabelas siswa yang menurut guru masih belum lancar membaca. Peneliti menemukan delapan orang siswa yang masih belum dapat membaca dengan lancar sedangkan empat siswa yang lain masih belum mengenal semua huruf sehingga saat membacapun masih suka menebak kata yang dibaca. Kedelapan siswa tersebut sudah mengenal semua huruf dan sudah dapat membaca, namun masih membutuhkan waktu yang lebih lama dalam menyelesaikan tugas membaca teks dibandingkan siswa-siswa lain. Rata-rata kecepatan membaca siswa tersebut berada di bawah 25 kata permenit. Saat membaca siswa-siswa tersebut: (1). Menghilangkan satu huruf atau sebaliknya, menambahkan huruf baik ditengah maupun di akhir kata, sehingga pengucapan kata tersebut menjadi berbeda. Misalnya: adab dibaca adap; (2). Memberikan jeda antar kata yang terlalu lama (lebih dari 3 detik); (3). Terbata-bata dalam membaca beberapa kata (mengeja), misalnya pada kata "lingkungan"; (4). Suka mengganti pengucapan huruf dari kata yang dibaca, seperti membaca zakat dengan jakat; (6). Suara yang dihasilkan saat membaca juga terdengar kurang jelas; (7). Terbalik dalam membaca kata, misalnya kara-raka.

Dari hasil wawancara dengan guru kelas I dan observasi di kelas, diperoleh kesimpulan bahwa masih terdapat siswa kelas I yang belum dapat membaca dengan lancar. Dari ke delapan siswa tersebut, kesalahan paling sering mereka lakukan adalah salah ucap, lambat dalam mengenal kata dan terbalik dalam membaca kata yang disajikan. Dari data tersebut peneliti melihat bahwa siswa tersebut masih terlambat dalam hal kesiapan membaca pada aspek kemampuan pengucapan kata. Menurut Indun (2012), aspek kesiapan membaca tersebut sudah mulai diajarkan sejak usia TK dan harus sudah matang sebelum siswa diajarkan membaca. Apabila kesiapan tersebut tidak terpenuhi, maka yang terjadi adalah siswa jadi lambat dalam membaca dan efek lebih jauh adalah pada kelas selanjutnya siswa akan sulit untuk memahami isi bacaan. Hal ini dikarenakan siswa masih disibukkan 
dengan pengenalan kata, sehingga perhatian terfokus pada proses pengenalan kata tersebut dan mengabaikan pemahaman. Jika kondisi ini terjadi pada siswa dikelas yang lebih lanjut, maka tidak tertutup kemungkinan siswa akan mengalami kesulitan belajar pada aspek membaca.

Berdasarkan permasalahan di atas, peneliti ingin melakukan penelitian dengan merancang suatu program intervensi untuk meningkatkan kelancaran membaca pada siswa kelas 1 SD. Rancangan pelatihan yang akan dilakukan berupa latihan pengucapan kata, dengan menggunakan pendekatan modifikasi perilaku.

\section{Proses Membaca}

Membaca merupakan proses memberikan makna yang dimaksudkan oleh penulis melalui simbol grafis dengan cara menghubungkannya dengan pengalaman seseorang (Dechant 1982, hal. 5). Definisi ini mengandung makna bahwa membaca terdiri dari 2 proses, yaitu (1) proses pengenalan kata yaitu identifikasi terhadap simbol tertulis (word identification) dan (2) proses asosiasi antara makna dengan simbol tertulis (comprehension). Pada tahap awal, pembaca harus melakukan analisis dengan mencari asosiasi antara simbol visual dengan suara (bunyi) sehingga apa yang dibaca dapat dikenali sebagai suatu kata yang mempunyai bunyi tertentu. Proses ini biasa disebut decoding.

Proses yang kedua adalah mengasosiasikan makna dengan simbol tertulis. Pada proses ini, pembaca memerlukan informasi lain berupa pengetahuan yang telah dimiliki yang akan dipakai untuk memberikan "makna" pada simbol tertulis. Sebagaimana konsep skemata, pengetahuan manusia sangat bervariasi tergatung dari seberapa banyak informasi dan seberapa besar pengalaman yang diperoleh dari lingkungan yang dapat disimpan dalam sistem ingatannya (djiwatampu, 1993).

\section{Tahap Perkembangan Kemampuan Membaca}

Chall (dalam santrock 2002) mengemukakan enam tahapan dalam perkembangan kemampuan membaca, dimulai dari ketermpilan prereading hingga kemampuan membaca yang sangat tinggi pada orang dewasa.yaitu:

Tahap 0 : Pre-reading, dari lahir hingga usia 6 tahun.

Pada tahap ini anak mulai memperoleh kontrol terhadap bahasa, dan berpura-pura untuk membaca. Pengalaman anak dalam mengembangkan tingkat ini berakhir disekitar usia 6 tahun.

Tahap 1: Initial reading/decoding stage, usia 6-7 tahun.

Selama tahap ini, anak mulai mengasosiasikan simbol dengan bunyi. Anak belajar membaca, belajar untuk melakukan decoding dan memahami tulisan. Anak menjadi sadar akan hubungan antara bunyi dan huruf dan berusaha mengaplikasikannya dalam tulisan. Penguasaan tahapan ini ditunjukkan dari anak sudah memahami konsep dari alfabet.

Tahap 2: Confirmation and fluency, 7-8 tahun.

Pada tahap ini anak mulai memperoleh kemampuan membaca yang cukup lancar dan mulai belajar menggunakan kemampuan decoding dalam membaca. Anak menjadi penasaran pada bacaan yang lebih banyak.

Tahap 3: Reading for learning the new, 914 tahun. Membaca untuk belajar.

Pada tahap ini, motivasi anak untuk membaca berubah. Anak sudah memiliki kemampuan untuk membaca teks guna memperoleh informasi. Kosakata anak berkembang dan meningkat.

Tahap 4: Multiple view points, 14-18 tahun.

Karakteristik utama dari tingkat ini adalah melibatkan lebih dari satu sudut pandang. Anak mengembangkan kemampuan untuk menghadapi berbagai fakta dan konsep yang anak tambahkan pada pengetahuan yang diperoleh pada tahap-tahap sebelumnya. 
Tahap 5: Construction and reconstruction, usia 18 tahun ke atas.

Tingkatan ini biasanya terjadi di bangku kuliah, di mana anak sudah berusia 18 tahun atau lebih tua. Pada tingkat ini anak sudah tahu tujuan dari membaca dan materi yang dibacanya. Tujuan dari membacapun bisa beragam. Anak bisa membaca dari awal, tengah atau akhir dari suatu bab. Anak memahami kualitas pengetahuan pada tingkat ini.

Pada penelitian ini, siswa yang menjadi subjek penelitian berusia antara 78 tahun, itu artinya tahap perkembangan membaca subjek seharusnya sudah berada pada tahap "confirmation and fluency". Namun yang terjadi adalah, siswa masih membutuhkan effort untuk melakukan aktivitas membaca dan masih membaca kata perkata.

\section{Kelancaran Membaca}

Samuel (2006) mendefinisikan kelancaran membaca sebagai kemampuan untuk mengenal kata dan memahami suatu bacaan pada waktu yang bersamaan.Teori ini diturunkan dari teori otomatisitas yang dikembangkan oleh Laberge \& Samuel (1974). Samuel (2006) menyimpulkan tiga komponen yang terdapat pada kelancaran membaca yaitu:

1) Ketepatan, merupakan kemampuan untuk mengenali atau mendekode katakata secara tepat.

2) Kecepatan, merupakan kemampuan untuk dengan cepat mengenali katakata secara otomatis.

3) Intonasi, merupakan kemampuan membaca dengan ungkapan yang tepat dan ekspresif (mengacu kepada kealamian dalam membaca), yaitu membaca teks dengan intonasi yang sesuai, tekanan irama yang mempengaruhi pengutaraan tanda baca dalam suatu bacaan. Prosody adalah indikator bahwa pembaca secara aktif membangun makna dari suatu bagian ketika mereka membaca.

Untuk dapat mengenal kata dengan tepat, siswa harus mampu mengidentifikasi suara yang dilambangkan oleh huruf atau kombinasi huruf (prinsip abjad), kemampuan untuk memadukan bunyi-bunyi secara bersama-sama, dan pengetahuan mengenai kata. Ketepatan mengenal kata yang buruk mempunyai pengaruh negatif yang jelas pada kelancaran membaca. Siswa yang membaca kata-kata secara tidak tepat tidak akan memahami pesan yang dimaksudkan penulis, dan pembacaan kata yang tidak akurat bisa menyebabkan salah tafsir terhadap bacaan yang dibaca.

Selanjutnya, untuk dapat membaca dengan lebih cepat, siswa harus dapat mengenal kata secara otomatis, sehingga dapat mengurangi beban kognitif dalam keterampilan membaca. Dengan demikian siswa dapat memusatkan perhatian untuk memahami isi teks. Pembacaan yang lambat bisa mengakibatkan pemahaman yang melemah. Untuk mengetahui kecepatan pengenalan kata dapat dilihat dari pengenalan dengan cepat pada kata yang dibaca. Dari sini dapat dinilai kemampuan siswa untuk mengenal secara otomatis kata-kata dengan menggunakan pengetahuan hubungan bunyi dengan simbol pada suatu kata. Nicholson (dalam Dechant, 1991) menyatakan bahwa kemampuan mengenal kata yang cepat (otomatis) akan mempengaruhi pemahaman membaca. Hal ini disebabkan karena dengan pengenalan kata yang cepat dan akurat memungkinkan siswa untuk (1). Menempatkan kata dalam memori jangka pendek dengan lebih cepat, (2). Memperluas dan mempercepat akses siswa dalam mencari makna yang paling tepat untuk kata tersebut, (3). Membaca lebih banyak kata sehingga dapat memanfaatkan konteks dengan lebih luas untuk mencari makna yang lebih tepat.

Terakhir, untuk dapat membaca dengan intonasi yang sesuai, siswa harus benar-benar memperhatikan tanda baca yang ada serta memberikan ekspresi yang sesuai (membaca dengan suara seperti berbicara) sehingga tidak merubah makna dari materi yang dibaca.Unsur-unsur yang 
mengisyaratkan adanya intonasi berupa tanda baca yang biasa digunakan dalam suatu bacaan, seperti tanda baca, tanda seru, titik, koma.

Pada penelitian ini, keterampilan yang akan diukur hanya pada tahap decoding kata. Oleh karena itu, peneliti hanya membatasi cakupan penelitian pada dua aspek pertama yaitu kecepatan dan ketepatan dalam membaca. Adapun alasan peneliti tidak memasukkan aspek ketiga adalah (1). Pada siswa kelas I proses membaca yang terjadi lebih pada proses pengenalan kata dan bentuk bacaan yang disajikan masih dalam bentuk kalimat sederhana yang terdiri dari tiga sampai lima kata dalam satu kalimat;. (2). Berdasarkan kurikulum pembelajaran kelas 1 dan 2, tujuan yang diharapkan adalah siswa dapat membaca kata dan kalimat sederhana dengan lancar dan lafal yang tepat, (3) Kecepatan dan ketepatan merupakan prediktor yang baik untuk kelancaran membaca pada tingkatan membaca kata dan kalimat, sedangkan intonasi merupakan prediktor yang sangat baik untuk kelancaran membaca dan pemahaman pada level bacaan. (klauda dan Guthrie, 2008, Samuel 2006).

\section{Latihan Pengucapan Kata}

Pengucapan kata merupakan salah satu syarat yang diperlukan untuk belajar membaca, yang diistilahkan dengan kesiapan membaca (Indun, 2013). Pada siswa kelas I yang pada dasarnya sudah dalam proses belajar membaca seharusnya sudah menguasai kemampuan pengucapan kata yang tepat. Namun pada beberapa siswa kemampuan tersebut belum dikuasai sepenuhnya, yang dapat ditandai dengan kemampuan membaca lancar yang masih rendah, masih suka salah ucap, berhenti/jeda untuk beberapa detik, ataupun membaca dengan artikulasi yang kurang jelas.

Setiap huruf memiliki aturan mengenai pergerakan otot alat ucap untuk mengeluarkan artikulasi pengucapan pada setiap hurufnya.Pengulangan artikulasi pengu- capan huruf ataupun kata perlu dilakukan untuk memahami adanya perbedaan identifikasi huruf atau kata. Salah satu cara untuk dapat memahami identifikasi huruf atau kata dan untuk dapat melakukan artikulasi pengucapan huruf atau kata adalah melalui latihan dengan melakukan pengulangan gerakan artikulasi pengucapan huruf atau kata. Melalui pergerakan artikulasi pengucapan huruf atau kata yang diulang-ulang, merupakan cermin untuk memperbaiki gerakan artikulasi pengucapan huruf atau kata yang masih salah (Indun, 2013).

Latihan pengucapan kata dianggap salah satu strategi yang efektif dilakukan untuk meningkatkan kelancaran membaca siswa, Dalam sebuah penelitian oleh Indun (2013) dijelaskan bahwa kemampuan membaca dapat ditingkatkan melalui gerakan alat ucap phoneme yang benar, dimana pada latihan pengucapan kata perhatian siswa difokuskan melalui beberapa indera meliputi visual dan auditori untuk mengoreksi kesalahan dalam mengucap kata. Latihan berulang yang dilakukan akan memungkinkan siswa untuk mengenal lebih banyak kosakata. Pada akhirnya diharapkan pembaca sepakat bahwa kata yang diucapkan secara baik, dapat diingat yang kemudian dapat direspon secara spontan bila dibutuhkan (Indun, 2013). Respon spontan yang dimunculkan disini dalam teori Laberge \& Samuel (1979) dikenal dengan istilah "automaticity", yaitu kemampuan siswa untuk dengan cepat mengenali kata-kata secara otomatis. Hal ini akan mengurangi beban kognitif siswa saat melakukan proses membaca.

Latihan pengucapan kata erat kaitannya dengan proses neurologis yang ada pada tubuh manusia yang digunakan dalam membaca yang bertalian antara otak manusia dengan sebagian besar bahasa. Seluruh sistem syaraf, terdiri dari dua bagian utama, yaitu (a) tulang punggung yang terdiri dari sederatan tulang punggung yang bersambung-sambungan (spinal cord) dan (b) otak. Otak itu sendiri 
terdiri dari batang otak (brain stem) dan korteks serebral (cerebral cortex). Tulang punggung dan korteks serebral merupakan sistem syaraf sentral manusia. Batang otak terdiri dari bagian-bagian medulla, pons, otak tengah dan cerebellum, berkaitan dengan fungsi fisikal tubuh (pernapasan, detak jantung, gerakan, refleks, pencernaan dan pemunculan emosi). Korteks serebral menangani fungsi intelektual dan bahasa. Korteks serebral manusia terdiri dari dua bagian: hemisfer kiri dan hemisfer kanan yang dihubungkan oleh 200 juta fiber korpus kalosum. Wujud fisik dari hemisfer kiri dan kanan hampir mrupakan pantulan cermin, tetapi ada sedikit perbedaan. Misalnya, di hemisfer kiri ada daerah Wernicke yang lebih luas daripada bagian yang sama di hemisfer kanan karena dalam kaitannya dengan bahasa yang paling banyak berperan adalah hemisfer kiri. Hemisfer kiri mempunyai empat daerah besar yang dinamakan lobe: lobe frontal (bertugas berkaitan dengan kognisi), lobe temporal (pendengaran), lobe osipital (penglihatan) dan lobe parietal (rasa somaestetik, rasa pada tangan, kaki dan muka). Pada lobe frontal terdapat daerah yang dikenal sebagai daerah Broca. Pada semua lobe terdapat girus (semacam gunduk atau bukit) dan sulkus (lembah atau bagian yang masuk ke dalam). Salah satu girus adalah girus angular yang berfungsi menghubungkan apa yang dilihat dan dengan apa yang dipahami didaerah Werniche, Sedangkan untuk menghubungkan apa yang dilihat dengan yang diujarkan, ada kelompok fiber yang dinamakan fasikulus arkuat. Tugas-tugas fiber, untuk mengkoordinasi pendengaran, penglihatan dan pemahaman yang diproses di daerah wernicke, dengan proses pengujaran daerah broca. Daerah broca agak ke belakang, ada jalur korteks motor yang bertugas mengendalikan alat ujaran seperti lidah, rahang, bibir, gigi dan pita suara (Dardjowijojo, 2003, Guyton 2008).

Fungsi otak yang berhubungan langsung dengan membaca merupakan bagian yang terpenting. Daerah di ujung posterior girus temporalis superior yang disebut daerahWernicke berperan dalam pemahaman informasi penglihatan dan pendengaran. Daerah ini berproyeksi melalui fasikulus arkuatus ke daerah broca yang berfungsi mengolah informasi yang datang dari daerah Wernicke menjadi pola yang terinci dan terkoordinasi untuk vokalisasi lalu memproyeksikan pola tersebut melalui area artikulasi atau pengucapan ke korteks motorik, yang mencetuskan gerakan bibir, lidah dan laring yang tepat untuk menghasilkan suara. Girus angularis di belakang daerah Wernicke mengolah informasi dari kata-kata yang dibaca sedemikian rupa sehingga kata-kata dapat diubah menjadi bentuk auditorik kata-kata daerah Wernicke (Ganong, 2003).

\section{METODE PENELITIAN}

Penelitian ini akan menggunakan pendekatan quasi-experiment, yaitu suatu rancangan penelitian yang digunakan untuk melihat pengaruh dari pemberian suatu perlakuan (treatment) terhadap permasalahan yang dilakukan pada setting seharihari. Desain yang akan digunakan dalam penelitian ini adalah Nonequivalent Control Group Design (Graziano, 2000). Dalam rancangan ini subjek penelitian dibagi menjadi dua kelompok experimental \& kelompok control. Kelompok experimental mendapat treatment latihan pengucapan kata, sementara kelompok control tidak mendapat treatment latihan pengucapan kata. Pengukuran dilakukan terhadap kedua kelompok penelitian tersebut sebelum dan sesudah pemberian treatment. Kemudian akan dilihat sejauh mana perubahan kemampuan kelancaran membaca subjek dengan cara membandingkan jumlah kata yang dapat dibaca oleh kedua kelompok subjek penelitian dalam waktu satu menit sebelum dan sesudah pelatihan.

Penjaringan subjek penelitian dilakukan dengan teknik purpossive sampling yaitu salah satu teknik pengambilan sampel non-probabilistik yang dilakukan 
berdasarkan kriteria yang disesuaikan dengan tujuan penelitian atau pertimbangan tertentu dari peneliti. Subjek dalam penelitian ini adalah siswa kelas I SD yang berdasarkan hasil asesmen awal memperoleh skor yang rendah dalam kelancaran membaca. Gambaran karakteristik dari subjek penelitian adalah sebagai berikut :

1. Siswa Sekolah Dasar kelas I (usia 7-8 tahun) yang belum lancar membaca.

2. Anak mengalami ketidaklancaran membaca disebabkan karena pergerakan otot alat ucap yang belum mencapai kematangan ditandai dengan membaca dengan pergerakan alat ucap yang tidak sesuai aturan sehingga sering melakukan kesalahan pengucapan.

3. Anak memiliki tingkat kecerdasan yang tergolong rata-rata. Data tingkat kecerdasan dilakukan dengan menggunakan PM colour.

4. Anak tidak mengalami masalah dalam atensi, yaitu dapat menunjukkan rentang perhatian yang cukup.

5. Anak tidak mengalami gangguan dalam indra pendengaran dan pergerakan bola mata saat membaca, karena kedua indera tersebut berkaitan dengan membaca.

6. Anak mengalami perkembangan bahasa yang normal, ditandai dengan anak sudah dapat mengerti kata-kata yang diucapkan orang lain dan mampu berbicara tanpa ada halangan atau gagap.

\section{HASIL PENELITIAN}

Latihan pengucapan kata yang diberikan pada subjek penelitian dalam penelitan ini bertujuan untuk meningkatkan kelancaran membaca subjek penelitian yang ditandai dengan bertambahnya jumlah kata yang dapat dibaca dengan tepat dan berkurangnya waktu yang dibutuhkan untuk membaca. Dari data hasil pretest dan posttest pada kelompok kontrol ditemukan bahwa tidak ada perbedaan kelancaran membaca antara sebelum dan sesudah pelatihan. Jika melihat pada perubahan yang diperoleh subjek pada tiap aspek kelancaran membaca, maka terlihat bahwa tidak meningkatnya kelancaran membaca pada subjek dikarenakan tidak terdapatnya perubahan yang signifikan pada aspek ketepatan dan kecepatan membaca. Pada subjek F, pada dasarnya terjadi peningkatan kecepatan membaca sebanyak 3 detik dan ketepatan membaca sebanyak 1 kata. Namun peningkatan tersebut tidak signifikan menunjukkan perubahan pda kelancaran membaca. Pada subjek DN juga terjadi peningkatan kecepatan membaca sebanyak 24 detik namun mengalami penurunan ketepatan membaca sebanyak 2 kata. Sedangkat pada subjek I, terjadi penurunan pada kedua aspek, yaitu penurunan kecepatan membaca sebanyak 39 detik dan ketepatan membaca sebanyak 1 kata.

Jika melihat perubahan yang tidak signifikan pada kelompok kontrol maka dapat disimpulkan bahwa subjek belum dapat dengan konsisten memberi pengucapan yang tepat pada setiap kata yang dibaca. Saat membaca subjek masih melakukan kesalahan membaca yang tetap. Hal ini kemungkinan disebabkan karena belum terlatihnya kemampuan artikulasi pengucapan kata yang tepat. Saat observasi juga terlihat bahwa dalam melakukan aktivitas membaca ketiga subjek masih kesulitan menempatkan (memposisikan) alat ucap dengan tepat sehingga pada saat subjek membaca, kondisi yang terjadi adalah ada bunyi yang hilang, ditambahkan, ditukar atau tidak diucapkan dengan jelas oleh subjek, baik di awal kata, di tengah kata maupun diakhir kata.

Untuk dapat mengucapkan kata dengan tepat, anak terlebih dahulu harus memiliki kemampuan untuk mengartikulasikan huruf dengan tepat. Setiap huruf memiliki aturan pergerakan alat ucap yang berbeda. Dari aturan yang berbeda tersebut akan menghasilkan suara yang berbeda, dari suara yang berbeda tersebutlah kemudian dipahami sebagai suatu phoneme. Pada subjek kelompok kontrol, masih terjadi pengucapan yang tidak mengikuti 
aturan, yang ditampilkan dari hasil membaca di mana masih bercampurnya suara konsonan dari kata yang dibaca. Subjek masih suka menghilangkan satu huruf yang sulit mereka ucapkan, atau menggantinya dengan huruf lain yang lebih mudah mereka ucapkan atau justru menambahkan satu huruf untuk memudahkan pengucapan yang memang masih sulit mereka pahami.

Sedangkan pada kelompok eksperimen, terjadi peningkatan kelancaran membaca pada 3 subjek dan tidak ada perubahan kelancaran membaca pada 1 subjek. Terjadinya peningkatan kelancaran membaca pada kelompok eksperimen memberikan arti terdapat peningkatan jumlah kata yang dapat dibaca subjek dalam waktu satu menit, sehingga dapat dikatakan proses decoding kata pada subjek mengalami peningkatan. Dari latihan yang dilakukan juga diketahui bahwa pada subjek A, J dan D terjadi peningkatan kemampuan pengucapan kata dengan tepat setiap harinya, subjek dapat lebih spontan memberikan pengucapan kata dengan cepat dan tepat. Hal ini menunjukkan bahwa kemampuan otot alat ucap subjek lebih terlatih dan lentur dalam memberikan pengucapan dan terdapat lebih banyak kata yang dapat diucapkan dengan tepat oleh subjek.

Jika melihat pada perubahan yang diperoleh pada setiap aspek kelancaran membaca, maka terlihat bahwa pada kelompok eksperimen, peningkatan kelancaran membaca dikarenakan meningkatnya skor pada aspek kecepatan dan ketepatan dalam membaca subjek. Yaitu, menurunnya jumlah waktu yang dibutuhan dalam membaca dan menigkatnya jumlah kata yang dapat dibaca dengan tepat selama proses membaca. Hanya saja, pada subjek $\mathrm{S}$ peningkatan yang terjadi tidak terlalu banyak. Penurunan waktu membaca yang hanya 13 detik dan dengan peningkatan jumlah kata yang tepat sebanyak 7 kata, belum menunjukkan perubahan pada meningkatnya kelancaran membaca subjek.
Aspek kecepatan, yang merupakan aspek utama dalam kelancaran membaca menunjukkan bahwa identifikasi kata dengan cepat dan tanpa usaha sangat penting karena ketika seseorang dapat membaca dengan spontan maka dapat menggunakan daya kognitif untuk memahami bacaan pada tingkat selanjutnya. Pada aspek ketepatan dalam membaca mengacu pada kemampuan untuk mengenali dan menguraikan kata secara benar tanpa melakukan kesalahan dalam pengucapan. Maksudnnya di sini untuk dapat mengenal kata dengan tepat saat melakukan aktivitas membaca, siswa harus dapat merasakan adanya hubungan antara kata yang diucap dengan bahasa tertulis dan memberikan pengucapan yang tepat pada kata yang dibaca tesebut. Untuk dapat melakukan pengucapan yang tepat, siswa perlu menggerakkan otot alat ucap. Pergerakan otot alat ucap yang tidak terlatih akan menghasilkan pengucapan kata yang lambat, sebaliknya pergerakan otot alat ucap yang lentur akan menghasilkan pengucapan kata yang lebih cepat dan tepat. Latihan pengucapan kata yang telah dilakukan menjelaskan bahwa proses neurologis dalam otak diaktifkan melalui pengucapan kata secara berulang dengan pergerakan otot alat ucap yang sesuai. Gerakan otot alat ucap yang semakin cepat dalam mengartikulasikan suatu kata akan memberi pesan lebih cepat pada otak untuk segera memberi respon sesuai harapan.

\section{SIMPULAN}

Berdasarkan analisis dari hasil yang diperoleh dari penelitian ini, maka dapat ditarik kesimpulan sebagai berikut:

1. Latihan pengucapan kata yang diberikan dapat meningkatkan kelancaran membaca pada 3 subjek dan terdapat 1 subjek yang tidak mengalami perubahan (tetap).

2. Subjek A mengalami peningkatan skor kelancaran membaca yang relative tinggi yaitu sebanyak 10 kata/menit. Terlihat perubahan kemampuan pengucapan kata pada 
subjek, terutama pada kata yang mengandung konsonan yang artikulator aktifnya pangkal lidah dan tengah lidah, yaitu pada huruf $\mathrm{k}, \mathrm{g}, \mathrm{h}$, ny. dan konsonan v, z. Penurunan kesalahan membaca kemungkinan disebabkan oleh terlatihnya otot alat ucap dan muncul control sehingga lebih "aware" pada pengucapan yang benar.

3. Subjek $\mathrm{J}$ mengalami peningkatan skor kelancaran membaca sebanyak 4 $\mathrm{kata} /$ menit. Terlihat perubahan pergerakan alat ucap yang lebih konsisten pada subjek, meskipun kadang masih terlihat kurang mau membuka mulut dan volume suara kecil. Sepanjang latihan terlihat sulit pada pengucapan huruf yang dihasilkan oleh pergerakan bibir, seperti huruf $f, v, b, p, m$ dan $w$. Penurunan kesalahan membaca saat posttest kemungkinan disebabkan oleh terlatihnya otot alat ucap dan muncul control sehingga lebih "aware" pada pengucapan yang benar.

4. Subjek D mengalami peningkatan skor kelancaran membaca sebanyak 5 kata/menit. Sepanjang latihan perlu diingatkan untuk lebih membuka mulut. Sulit pada konsonan yang pengucapannya hampir sama seperti $p$ dan $b$, f dan $v, z$ dan $j$, dan juga konsonan yang pengucapannya menggunakan ujung lidah, yaitu konsonan $\mathrm{d}, \mathrm{t}$ dan n. Penurunan kesalahan membaca kemungkinan disebabkan oleh terlatihnya otot alat ucap dan muncul control sehingga lebih "aware" pada pengucapan yang benar.

5. Subjek $\mathrm{S}$ tidak mengalami perubahan skor kelancaran membaca. Hal ini kemungkinan disebabkan karena pergerakan otot alat bicara yang masih kurang lentur dan tidak konsisten dalam pengucapan kata. Subjek S menolak pada latihan pengucapan huruf $r$ sehingga pengucapan kata yang mengandung huruf $r$ masih belum tepat. Subjek S kurang mampu mengontrol pengucapan yang lebih tepat, sehingga lebih sering melakukan kesalahan.

6. Faktor fisik dan psikis mempengaruhi subjek untuk melakukan latihan pengucaan kata sehingga mempengaruhi kelancaran membaca subjek sebagai hasil dari latihan yang dilakukan. Faktor fisik yang mempengaruhi beberapa subjek dalam melakukan latihan pengucapan kata adalah pergerakan otot alat ucap yang masih kaku sehingga subjek lebih sulit dalam mengikuti pengucapan yang tepat jika dibandingkan dengan subjek yang lebih lentur dalam hal pengucapannya. Kondisi ini berpengaruh pada motivasi dan kessediaan subjek untuk lebih bersungguh-sungguh mengikuti latihan pengucapan tersebut.

\section{SARAN}

Saran yang dapat diberikan dalam penelitian ini adalah:

1. Perlu diberikan jumlah materi kata yang lebih banyak pada huruf yang masih sulit diucapkan oleh anak agar anak mendapat penngulangan latihan dengan variasi kata yang lebih beragam.

2. Perlu adanya latihan lanjutan bagi subjek, mengingat berbagai keterbatasan dan kondisi selama pemberian latihan yang kurang optimal, seperti kondisi mood subjek yang berubah-ubah, kondisi fisik subjek penelitian yang bervariasi, seperti subjek $\mathrm{S}$ yang memiliki gerakan otot alat ucap yang lebih kaku, serta waktu yang terbatas.

3. Bagi subjek yang memiliki gerakan otot alat ucap yang lebih kaku, akan lebih baik mengikuti latihan yang lebih mendasar sebelum mengikuti latihan pengucapan kata, seperti latihan membuka mulut, menggerak-gerakkan alat ucap dengan rutin secara berulangulang.

4. Penelitian selanjutnya dapat dilakukan dalam jumlah subjek yang lebih banyak, untuk mendapatkan data 
kuantitatif yang lebih banyak dengan perhitungan statistik.

\section{DAFTAR PUSTAKA}

Arifuddin. 2010. Neuro Psikolinguistik. Jakarta: Rajawali Press.

Azwar, Saifuddin. 2004. Reliabilitas dan Validitas. Jakarta Pustaka Pelajar.

Breznitz, Zvia. 2006. Fluency In Reading : Synchronization of Processes. Lawrence Erlbaum Association, Publisher. New Jersey.

Burn, Paul.C, Roe, B.D, Ross, E.P. 1984.Teaching Reading in Today's Elementary School. Houghton Mifflin Company. New Jersey.

Darjowijoyo. 2003. Psikolinguistik: Pengantar Pemahaman Bahasa Manusia. Jakarta: Yayasan Obor Indonesia

Dechant, E. V. 1982. Improving the Teaching of Reading 3rd Ed. Prentice Hall Inc. New Jersey.

Dudley, Anne M. 2005. Dissertation. Effect of Two Fluency Methods on The Reading Performance on Secondary Student. The University of Arizona.

Graziano, A. M. \& Raulin, M. L. 2000.Research Methods: A Process of Inquiry. Allyn and Bacon. Boston.

Guyton \& Hall. 2008. Buku Ajar: Fisiologi Kedokteran. Alih Bahasa: dr. irawati dkk. Jakarta: EGC

Harris, A. J. \& Sipay, E. R. 1980.How to Increase Reading Ability : A Guide to Developmental and Remedial Methods 7th Ed. Longman, Inc. New York.

Hudson, R.F; Lane, H.B; Pullen, P.C. 2005. Reading Fluency Assessment and Instruction: What, Why and How? Jurnal International Reading Association.

Indun, Lestari S. 2013.Efektifitas Pencapaian Kesiapan Membaca Melalui Pelatihan Artikulasi Pengucapan Kata Pada Siswa TK
Di Bandung.Disertasi. Universitas Padjajaran.

Lott, Deborah. 2007. Super Star Speech: Speech Therapy Made Simple.Super Star DML Publishing. Alabama.

Marsono. 2008. Fonetik. Yogyakarta: Gajah Mada University Press.

Myers, P. L. and Hammill, D. D. 1976.Methods for Learning Disorders, 2nd Ed. John Wiley and Sons. Toronto.

Pikulski, John.J. 2006. Fluency: $A$ Developmental and Language Perspective. Dalam Farstrup, A. E. \& Samuels, S. J.What Research Has to Say About Fluency Instruction, $3 r d E d$. International Reading Association.

Rasinki, Timothy, V. 2006. A Brief History of Reading Fluency.Dalam Farstrup, A. E. \& Samuels, S. J.What Research Has to Say About Fluency Instruction, 3rd Ed. International Reading Association.

Samuel, S. J. 1979. The Method of Repeated Reading.The Reading Teacher.

Samuels, S. J. 2002. Reading Development: Its Development and Assesment.Dalam Farstrup, A. E. \& Samuels, S. J.What Research Has to Say About Reading Instruction, 3rd Ed. International Reading Association.

Samuels, S. J. 2006. Toward a Model of Reading Fluency. Dalam Farstrup, A. E. \& Samuels, S. J.What Research Has to Say About Fluency Instruction, $3 r d \quad E d$. International Reading Association.

Santrock, J. W. 2007. Child Development, 11th Ed, Mc. Graw- Hill International Edition.

Sastra, Gusdi. 2011. Neurolinguistik. Bandung: Alfabeta.

Smith.N.A. \& Robinson, H.A. 1980.Reading Instruction for Today's Children 2nd Ed. Prentice Hall Inc. New York. 
Vallet, Robert E. Ed.D. 1969. Programmimg Learning Disabilities. California: California State University

Willis, Judy M.D. 2008. Teaching The Brain to Read: Strategies for Improving Fluency, Vocabulary, and Comprehension. Association for upervision and Curriculum Development.Virginia USA
Widyna, Rahma. 2009. Hubungan antara Persepsi Visual dan Kemampuan Membaca Siswa Kelas 1-2 Sekolah Dasar. Yogyakarta: Fakultas Psikologi Mercu Buana.

Windiarini, Yunita Endah. 2008. Tesis: Neurological Impress Method untuk Meningkatkan Kemmpuan Membaca Permulaan Pada Siswa Kelas I Sekolah Dasar. Semarang: Fakultas Psikologi Universitas Katolik Soegijapranata. 